\title{
Model Suggestion for the Investigation of the Textbooks to Be Used In Teaching Turkish as a Foreign Language
}

\author{
Dr. Engin ÖMEROĞLU
}

\begin{abstract}
Textbooks are considered the most important course materials from past to present. Qualified and functional textbooks are required to achieve the desired objectives of education. Therefore, the processes of examining the textbooks to be used in teaching Turkish as a foreign language and carrying out scientific research on this subject is modelled in this article. A qualitative research method was used in this article. Both quantitative and qualitative data might be used in the studies carried out to examine the textbooks used in teaching Turkish as a foreign language. Therefore, the mixed methods research can be regarded as a suitable research design for examining textbooks. For the quantitative data, a 5-point Likert-type scale can be applied to instructors who use the textbooks, while a Rubrics can be applied to students. Also, the qualitative data obtained from researcher's field notes, observations, interviews with the participants (instructors, students, and the experts of book design and printing), the questionnaires to be applied to them, and the analysis of the textbooks subject to research, as well as, the quantitative data obtained from checklists and semantic scales can be evaluated by following a holistic approach.
\end{abstract}

Keywords: Teaching Turkish as a foreign language, Textbooks, Research Method, Data Collection Tools.

\section{Introduction}

In order to achieve the desired objectives in foreign language teaching, the textbooks to be used in the courses have to be qualified, functional, and designed to meet the scientific criteria. Therefore, clarifying the issue of how to choose textbooks to be used in foreign language teaching and how to investigate and examine these books are important in terms of establishing scientific standards. Above all, it may be necessary to review the definition of the term textbook: "The textbook is a book prepared to teach knowledge about various disciplines and consisting of systematic and organized texts ranging from easy to difficult" (Richaudeau \& Gauquelin, 1997: 30). "Textbooks are important resources that significantly affect what the teachers will teach and what the students will learn in the teaching-learning process, particularly in planned educational practices" (Küçükahmet, 2011: 18). "As an instrument that is easy to use and accessible to all students, textbooks provide knowledge directly, can be used continuously, can be referenced any time, and they can fill the gaps of verbal education" (Bamberger, 1975: 5).

While the textbooks to be taught in primary and secondary education are determined by the Republic of Turkey Ministry of National Education (MEB), there are no formal criteria for the textbooks to be used in teaching Turkish as a foreign language. However, the scientific studies, publications, the principles established by the European Council, of which Turkey is also a member, reveal the criteria of the textbooks to be used in teaching Turkish as a foreign language.

\subsection{Research Problem and Purpose}

The processes of examining the textbooks to be used in teaching Turkish as a foreign language and foreign language teaching in general and carrying out scientific research on this subject is modelled in this article. In this context, the statement of the research problem is "How can scientific research on textbooks used/to be used in teaching Turkish as a foreign language be carried out, which method is suitable for such research, and from which source can the data be collected? Are there criteria for the textbooks used in teaching Turkish as a foreign language? Can these criteria be established?"

\section{Method}

This article, which models how to examine the textbooks used in teaching Turkish as a foreign language, is an outcome of a qualitative research study. "Qualitative research is an approach that prioritizes understanding 
social phenomena in their environment with an understanding based on creating theory" (Yıldırım \& Şimşek, 2013: 45). In other words, "qualitative research is a research method that constructs general patterns using inductive approach" (Patton, 2014: 56). In this research, it is explained how the textbooks used in teaching Turkish as a foreign language can be examined, from which source the data can be obtained for examining textbooks, how can these data be evaluated to develop a theory on this subject by following an inductive understanding.

\section{Findings and Comments}

To conduct scientific research on textbooks used in teaching Turkish as a foreign language, it is necessary to identify the problem(s) in this subject in the first stage. Because "The research studies are processes for solving problems, and any challenge that needs to be solved is a problem. The research problems fall into two groups: general and specific" (Karasar, 2013: 54-55). Therefore, to be able to conduct a scientific study in this field, general and specific problems need to be identified at the first stage; then, an appropriate research method and data collection tools need to be determined to solve this/these problem(s).

In this case, what is the general and specific problem in teaching Turkish as a foreign language?

International students are required to know Turkish at the $C$ - 1 level to start their undergraduate education at universities in Turkey. Therefore, the students go to Turkish Language Teaching Centres (TÖMER, in either) Turkey or abroad to learn Turkish. The students who graduated from these centres begin their undergraduate education at universities in Turkey, and they study at various programs together with other students whose native language is Turkish under the same conditions.

In this case "Do the students, who begin their undergraduate education by getting $C$-1 Certificate from TÖMER (in either) have the proficiency in Turkish to follow these courses?"

\section{General Problem:}

The observations and findings show that the students have problems particularly, in the first years, even in further years. The students' lack of proficiency in Turkish is occasionally reported as a matter of complaint by the instructors of various fields. The fact that some students are not able to understand what is taught in the lessons, although they received $C$ - 1 certificates from teaching Turkish as a foreign language particularly, and that they have difficulties in writing skills are the general problems.

\section{Specific Problem:}

Various reasons and specific problem(s) can be the cause of the general problem described above.

For example;

(1) The textbooks and other materials used in the courses may be unqualified and not designed well.

(2) The program applied, and the language teaching methods may be unsuitable.

(3) It may originate from the instructor or the teaching environment.

(4) The level/achievement of the student who received a $C-1$ certificate may not reflect the truth.

One of the above specific problems causing the general problem to arise can be considered as the subject of research:

Are the textbooks used in TÖMER (in either) designed according to scientific criteria, are they in line with the aimed gains in teaching Turkish as a foreign language?

Determining such a problem and the studies on its solution are also significant for the aimed gains from education. Because "instructional technologies and material design are considered to be the most determining factors in making educational services qualified" (Demirel \& Altun, 2012: 1). "The most important contribution of textbooks to education is that they facilitate the education/training process and improves the efficiency of education" (Güneş, 2002: 3). Therefore, the textbooks used in teaching Turkish as a foreign language need to be designed according to scientific criteria, and other materials used with the textbooks should be qualified. Other tools and course materials used together with textbooks are also important for teaching foreign languages. These course tools and materials can be "linguistic, visual, visual, 
auditory or kinaesthetic, they can be presented in writing, by performance or playing by DVD or on the Internet" (Tomlinson \& McGrath, 2002: 7).

Researching and solving this specific problem related to textbooks and other materials may also contribute to the solution of the general problem.

Textbooks can be examined and evaluated based on their two features: formal (external structure) properties and content properties. For the formal properties (external structure) of the textbooks, the factors such as size, print quality, paper, binding, cover, colour preference, design of visual elements, fonts, compatibility of visual elements with the subject, text preference can be evaluated. On the other hand, the content properties of textbooks can be evaluated considering their education/training aspect, language and expression, orthography and punctuation features, sociological aspect, and compliance to European Language Portfolio (Euro pass) This way of evaluation requires that the specific problem mentioned above should be addressed under two issues:

(1) "Are the textbooks used in teaching Turkish as a foreign language qualified in terms of their formal (external structure) properties and designed according to the required scientific criteria?

The answer to this question is significant for a qualified foreign language teaching because a textbook should have the required physical qualities such as its cover, weight, paper, and carton quality, binding, size, practicability, and durability (Ar1, 2014: 39). Besides the physical and technical factors, the visual elements need to be well organized in the textbooks. Because, it is a fact that the quality of education/training increases in line with the increase in the visual stimuli (Kılıç \& Seven, 2011: 35).

(2) "Are the textbooks used in teaching Turkish as a foreign language qualified and functional in terms of their content properties and designed according to the required scientific criteria?"

All factors need to be taken into consideration while creating content also for the textbooks to be prepared (Küçükahmet, 2011: 22). The textbooks to be prepared for teaching Turkish as a foreign language need to include grammar and assessment and evaluation elements together with the basic language skills, and all these elements should be taken into account while creating content in the books.

The sub-problems associated with the above-mentioned problems can be listed as follows:

\section{Research Questions:}

To find answers to the question of "Are the textbooks used in teaching Turkish as a foreign language qualified in terms of their formal (external structure) properties and content properties and designed according to scientific criteria?", the following questions may be research questions:

(1.) How are the textbooks prepared for teaching Turkish as a foreign language designed in terms of their formal properties (external structure)?

The following questions can be asked about the textbook:

- How is its print quality?

- How is its cover design?

- Is its paper of good quality?

- Is its binding durable?

- How is its page layout designed?

- Are the colour preferences proper?

- How is the design of the visual elements?

- Are the visual elements compatible with the content?

- Are the fonts and sizes suitable?

(2). How are the textbooks prepared for teaching Turkish as a foreign language designed in terms of their content properties?

The following questions can be asked about the textbook:

- Is it suitable for developing basic language skills such as reading, listening, speaking, and writing?

- Is it suitable for the European Language Portfolio (CEFRL)? 
- Are the units suitable for levels (Euro pass: $A-1, A-2 ; B-1, B-2 ; C-1, C-2$ )?

- Are the activities of the units sufficient for the aimed gains?

- Are the activities of the units properly ordered?

- Do the contents (activities) of the units motivate the student?

- How do listening and watching activities contribute to learning objectives?

- Are the audio and video files on the DVD supplied with the textbook well organized?

- Are the audio and video files compatible with the topics in the book?

- Are speaking activities (dialogue practices) well organized?

- Are the speaking activities suitable for the aimed gains?

- Are the writing activities well organized?

- Is the selection of reading texts suitable?

- Does the selection of reading texts motivate the student?

- Are the sections for grammar topics sufficient?

- Is the order of grammar topics suitable?

- Are the grammar topics compatible with the texts in the book?

- Are assessment and evaluation questions sufficient, can they measure what is taught?

- Is it impeccable in terms of language and expression, orthography, and punctuation?

- Are there arrangements for cultural interaction?

- Is it compatible with universal and human values?

These research questions can be increased or decreased according to specific situations.

\section{Data Collection Tools:}

In the process of evaluation and selection of textbooks, from which source(s) the data will be collected is an important issue. The data can be collected from students, instructors, the experts on this field, publishers, and graphic designers to evaluate textbooks prepared for teaching Turkish as a foreign language (Kılıç et al., 2011: 195). However, international students need to speak Turkish at least at the $B-1$ level to be eligible to collect data from these students. Also, each textbook can be considered another information/data collection tool. Moreover, the examination/analysis that the researcher will make on the existing textbook(s) can also be considered as a data collection tool that complements all of them.

(1) Qualitative Data: Qualitative data can consist of interviews (interview minutes) with instructors and field notes, observations (Patton, 2014: 4). The researcher can meet with the instructors who use the textbook and make interviews with them using the interview form prepared before. Also, the researcher can make interviews with the students who use the textbook to collect data. The questions already prepared are asked to participants from both groups, their answers can be recorded using a recording device such as a voice recorder, etc. The researcher may also meet/make interviews with book designing experts, press and publishing professionals, publishing house employees/owners. A questionnaire may be applied to them during the interview. The researcher can also add his/her own observations to all these data. All of the notes and records he took during the interview can be used as data There may be instances where the interviewees and documents cover the observations that matter. The observations, also called field notes have descriptive features. Open-ended questions to be asked in the interviews can be prepared in advance. However, these questions can be changed, and additions can be made during the interview. The entire conversation during the interview needs to be recorded using a recording device such as a voice recorder, etc. If the researcher does not have the opportunity to make face-to-face interviews, the interviews can be made via phone, email, or using other audio-visual materials (Creswell \& Clark, 2015: 189). Recording the data allows the researcher to review the notes taken for later analyses; also, it may also allow the person who read the findings of the research to experience the activities observed in the research.

(2) Quantitative Data: In textbook evaluations or investigation on textbooks, tools can be developed to be applied to both the instructors and the students using the book to determine the sufficiency of the textbook. For example, a 5-point Likert-type scale can be developed and applied to instructors. On the other hand, a rubric can be applied to the students. "A rubric is a tool that shows students the criteria that will be used to evaluate their work, and the score their performance corresponds to" (Tekin, 2019). However, such a rubric 
can only be applied to international students in teaching Turkish as a foreign language if they have the language proficiency of at least the $B-1$ level.

Besides, checklists and semantic scales can also be developed. The quantitative data from all these applications can be combined with qualitative data to evaluate the textbooks following a holistic approach.

Examples of the Checklist, Semantic Scale, Likert-Type Scale, and Rubrics that can be applied in teaching Turkish as a foreign language are presented below.

Checklist:

A checklist can be used in the evaluation and selection of the textbooks to be used in teaching Turkish as a foreign language. "The checklist is the list of items to be checked. Checklists can be used to measure qualifications and situations." (Polland, 1998). A checklist is presented as an example in the table below.

\section{Table 1: Checklist Example}

\begin{tabular}{|l|l|}
\hline \multicolumn{2}{|l|}{ Teaching Aids } \\
\hline Textbook: \\
$\begin{array}{l}\text { PVD file created in compliance with the textbook to be used with a } \\
\text { projector: }\end{array}$ & \\
\hline Teacher's Edition of the Textbook & \\
\hline DVD files prepared for listening/watching activities: & \\
\hline Additional materials (Flashcards, playing cards, etc.) & \\
\hline Total Score: & $\begin{array}{l}\text { The maximum score that can be } \\
\text { obtained from this list }=5\end{array}$ \\
\hline $\begin{array}{l}\text { Scoring } \\
\text { Present }=1\end{array}$ & \\
Absent $=0$ &
\end{tabular}

Also, the checklist example given in the table above can be developed for different elements of the textbook such as its assessment and evaluation section, the compliance of visual elements with text, cultural interaction, etc.

\section{Semantic Scales:}

The semantic scale is an evaluation method carried out using questions requiring opposite and different answer options (good, moderate, weak, yes, no, partially, etc.) However, it may be difficult for the participant to decide on the answer options in the semantic scales.

In the table below, there is an example semantic scale that can be used in the evaluation of textbooks used in teaching Turkish as a foreign language.

\section{Table 2: Semantic Scale Example}

\begin{tabular}{|l|l|l|l|}
\hline & Good/Yes & Moderate/Partially & Weak/No \\
\hline $\begin{array}{l}\text { The paper of the } \\
\text { textbook }\end{array}$ & & & \\
\hline Binding of the textbook & & & \\
\hline $\begin{array}{l}\text { Page layout of the } \\
\text { textbook }\end{array}$ & & & \\
\hline $\begin{array}{l}\text { The print quality of the } \\
\text { textbook }\end{array}$ & & & \\
\hline Is the textbook's cover & & & \\
\hline
\end{tabular}




\begin{tabular}{|l|l|l|l|}
\hline attractive? & & & \\
\hline $\begin{array}{l}\text { Is the textbook's cover } \\
\text { of good quality? }\end{array}$ & & & \\
\hline Total: & & & \\
\hline $\begin{array}{l}\text { The maximum score that can be obtained } \\
\text { from this scale: } 21 \text { points. }\end{array}$ & Grand Total: & \\
Good/Yes: 3; Moderate/Partially: 2; & & \\
Weak/No: 1 point.
\end{tabular}

\section{Likert-type Scale:}

A Likert-type scale can be developed and applied to students and instructors using the textbook in teaching Turkish as a foreign language. However, such a scale and rubrics can only be applied to students if they have the Turkish language proficiency of at least the B-1 level or above, and also, the scale needs to be simpler and clearer.

In the table below, there is a 5-point Likert-type scale developed by Ömeroğlu (2016) to determine both the external structure and content properties of the textbooks used in teaching Turkish as a foreign language. This scale was applied to instructors at teaching Turkish as a foreign language centre (TÖMER. in either).

The qualitative and quantitative data obtained from all the data collection tools described briefly above can be evaluated by the researcher using a holistic approach, and the textbooks can be analysed. Thus, a conclusion can be drawn for the textbooks examined.

\section{Table3: 5-Point Likert-Type Scale (Ömeroğlu, 2016)}

Demographic Data:

Gender: Female ( ) Male ( )

Age: .......

How long have you been teaching Turkish as a foreign language?.

Degree: Undergraduate ( ) Master of Science ( ) Doctorate ( )

How many different textbooks have you used so far, please write down their titles:

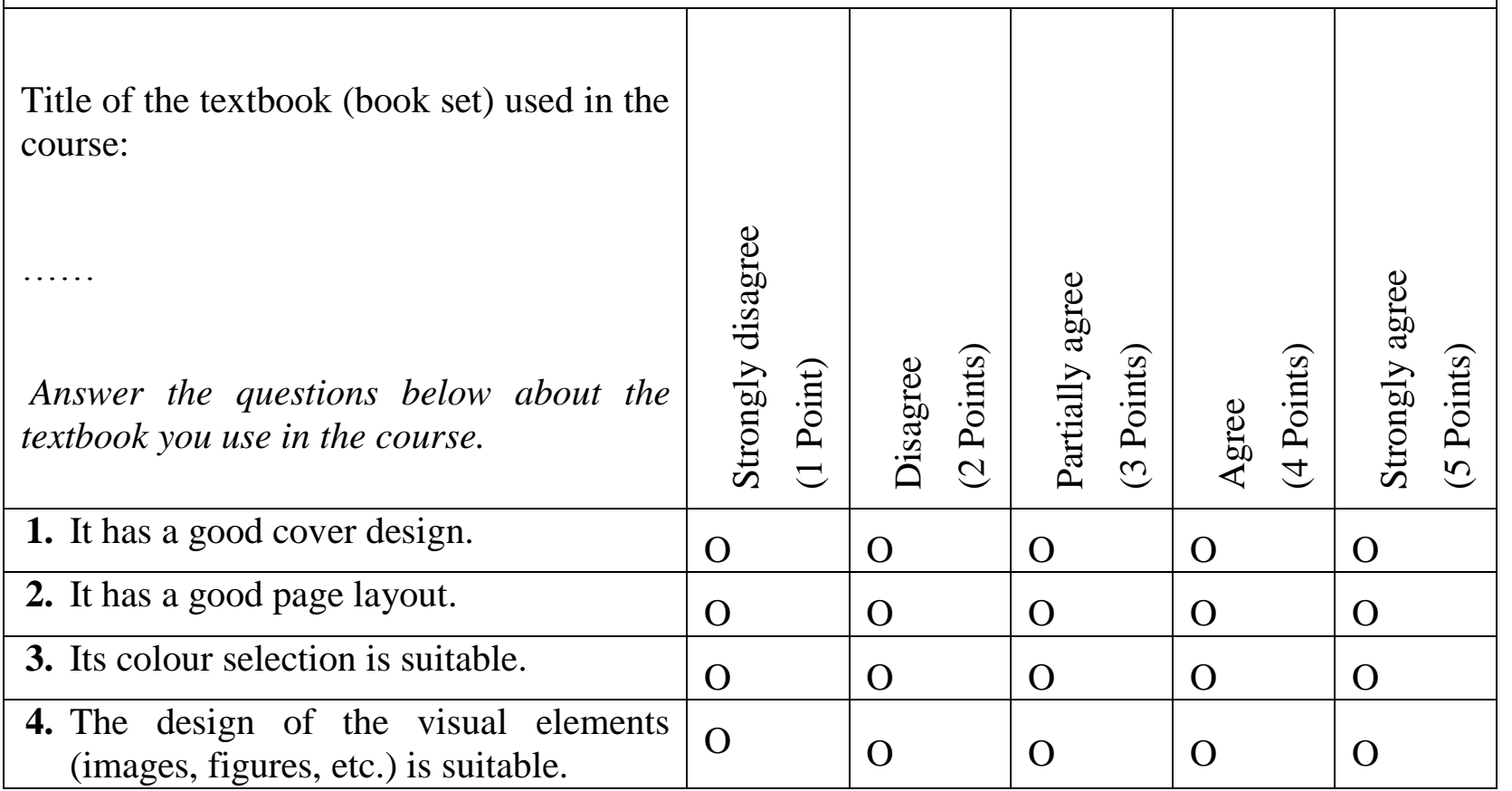




\begin{tabular}{|c|c|c|c|c|c|}
\hline $\begin{array}{l}\text { 5. The visual elements are compatible } \\
\text { with the content. }\end{array}$ & $\mathrm{O}$ & $\mathrm{O}$ & $\mathrm{O}$ & $\mathrm{O}$ & $\mathrm{O}$ \\
\hline $\begin{array}{l}\text { 6. It is suitable to develop students' basic } \\
\text { language skills such as reading, } \\
\text { listening, speaking, and writing. }\end{array}$ & $\mathrm{O}$ & $\mathrm{O}$ & $\mathrm{O}$ & $\mathrm{O}$ & $\mathrm{O}$ \\
\hline $\begin{array}{l}\text { 7. The number of units is suitable for the } \\
\text { level. }\end{array}$ & $\mathrm{O}$ & $\mathrm{O}$ & $\mathrm{O}$ & $\mathrm{O}$ & $\mathrm{O}$ \\
\hline $\begin{array}{l}\text { 8. Activities within the units are } \\
\text { sufficient. }\end{array}$ & $\mathrm{O}$ & $\mathrm{O}$ & $\mathrm{O}$ & $\mathrm{O}$ & $\mathrm{O}$ \\
\hline $\begin{array}{l}\text { 9. The activities within units motivate the } \\
\text { student. }\end{array}$ & $\mathrm{O}$ & $\mathrm{O}$ & $\mathrm{O}$ & $\mathrm{O}$ & $\mathrm{O}$ \\
\hline $\begin{array}{l}\text { 10. The audio (video) files on DVD } \\
\text { are of good quality. }\end{array}$ & $\mathrm{O}$ & $\mathrm{O}$ & $\mathrm{O}$ & $\mathrm{O}$ & $\mathrm{O}$ \\
\hline $\begin{array}{l}\text { 11. The audio (video) files are } \\
\text { compatible with the unit. }\end{array}$ & $\mathrm{O}$ & $\mathrm{O}$ & $\mathrm{O}$ & $\mathrm{O}$ & $\mathrm{O}$ \\
\hline $\begin{array}{l}\text { 12. The speaking activities (dialogue } \\
\text { practices) are sufficient. }\end{array}$ & $\mathrm{O}$ & $\mathrm{O}$ & $\mathrm{O}$ & $\mathrm{O}$ & $\mathrm{O}$ \\
\hline $\begin{array}{l}\text { 13. The writing activities are } \\
\text { sufficient. }\end{array}$ & $\mathrm{O}$ & $\mathrm{O}$ & $\mathrm{O}$ & $\mathrm{O}$ & $\mathrm{O}$ \\
\hline $\begin{array}{l}\text { 14. The reading activities are } \\
\text { sufficient. }\end{array}$ & $\mathrm{O}$ & $\mathrm{O}$ & $\mathrm{O}$ & $\mathrm{O}$ & $\mathrm{O}$ \\
\hline $\begin{array}{l}\text { 15. The reading texts are good and } \\
\text { motivate the student. }\end{array}$ & $\mathrm{O}$ & $\mathrm{O}$ & $\mathrm{O}$ & $\mathrm{O}$ & $\mathrm{O}$ \\
\hline 16. The grammar topics are sufficient. & $\mathrm{O}$ & $\mathrm{O}$ & $\mathrm{O}$ & $\mathrm{O}$ & $\mathrm{O}$ \\
\hline $\begin{array}{l}\text { 17. The order of the grammar topics } \\
\text { given is suitable. }\end{array}$ & $\mathrm{O}$ & $\mathrm{O}$ & $\mathrm{O}$ & $\mathrm{O}$ & $\mathrm{O}$ \\
\hline $\begin{array}{l}\text { 18. The grammar topics are compatible } \\
\text { with the text. }\end{array}$ & $\mathrm{O}$ & $\mathrm{O}$ & $\mathrm{O}$ & $\mathrm{O}$ & $\mathrm{O}$ \\
\hline $\begin{array}{l}\text { 19. The assessment and evaluation and } \\
\text { exercise questions are sufficient. }\end{array}$ & $\mathrm{O}$ & $\mathrm{O}$ & $\mathrm{O}$ & $\mathrm{O}$ & $\mathrm{O}$ \\
\hline $\begin{array}{l}\text { 20. The contribution of the student's } \\
\text { workbook and teacher's edition of the } \\
\text { textbook to learning objectives is } \\
\text { sufficient. }\end{array}$ & $\mathrm{O}$ & $\mathrm{O}$ & $\mathrm{O}$ & $\mathrm{O}$ & $\mathrm{O}$ \\
\hline $\begin{array}{l}\text { 21. The practicability and functionality } \\
\text { of the student's workbook are } \\
\text { sufficient. }\end{array}$ & $\mathrm{O}$ & $\mathrm{O}$ & $\mathrm{O}$ & $\mathrm{O}$ & $\mathrm{O}$ \\
\hline $\begin{array}{l}\text { 22. The practicability and functionality } \\
\text { of the teacher's edition of the textbook } \\
\text { is sufficient (leave blank if not } \\
\text { available) }\end{array}$ & $\mathrm{O}$ & $\mathrm{O}$ & $\mathrm{O}$ & $\mathrm{O}$ & $\mathrm{O}$ \\
\hline $\begin{array}{l}\text { 23. I make additions or eliminations } \\
\text { to/from the activities and topics in the } \\
\text { textbook when needed. }\end{array}$ & $\mathrm{O}$ & $\mathrm{O}$ & $\mathrm{O}$ & $\mathrm{O}$ & $\mathrm{O}$ \\
\hline $\begin{array}{l}\text { 24. It has a firm structure in terms of } \\
\text { language and expression, and } \\
\text { orthography and punctuation. }\end{array}$ & $\mathrm{O}$ & $\mathrm{O}$ & $\mathrm{O}$ & $\mathrm{O}$ & $\mathrm{O}$ \\
\hline $\begin{array}{l}\text { 25. It is compliant with the European } \\
\text { Language Portfolio. }\end{array}$ & $\mathrm{O}$ & $\mathrm{O}$ & $\mathrm{O}$ & $\mathrm{O}$ & $\mathrm{O}$ \\
\hline $\begin{array}{l}\text { 26. The textbook covers cultural } \\
\text { transfer. }\end{array}$ & $\mathrm{O}$ & $\mathrm{O}$ & $\mathrm{O}$ & $\mathrm{O}$ & $\mathrm{O}$ \\
\hline
\end{tabular}


27. The book is compliant with universal human values.

\begin{tabular}{l|l}
$\mathrm{O}$ & $\mathrm{O}$
\end{tabular}

$\mathrm{O} \quad \mathrm{O}$

$\mathrm{O} \quad \mathrm{O}$

$\mathrm{O}$

If you would like to add notes other than these, please write them overleaf....

\section{Rubrics:}

Rubrics are one of the most common measurement tools used in performance evaluation with its structure of reflecting performance levels, Rubrics minimize bias that may occur during scoring; also, they can provide students with more realistic and detailed feedback on their performance (Parlak \& Doğan, 2014: 190). Rubrics are powerful tools for evaluation due to many reasons and therefore the most common argument for using rubrics is that they help to define the 'quality' (Andrade, 1997). Therefore, the Rubric to be applied to students using the textbook in teaching Turkish as a foreign language can provide useful data to the researcher. However, some stages and features should be known while preparing the rubrics. Kilıç (et al., 2011: 197) listed these technical principles as follows:

Continuity: The scores must be of equal value and summable. For example, the interval between 5 and 4 should be equal to the interval between 2 and 1 .

Parallelism: The performance of each level should be identified with its opposite. For example, low-skilled, moderate-skilled, high-skilled

Definition: A high-level language should be used in the definition, and all levels could be definitely separated from each other.

Validity and reliability: The factors of choosing the right measurement tools, defining the levels clearly to be understood by everyone, and accurate scoring are significant for the validity and reliability of the rubric.

The table below contains an example rubric that is prepared in accordance with the above descriptions and can be applied to students.

\section{Table 4: Rubrics Example}

\begin{tabular}{|c|c|c|c|c|}
\hline PROPERTIES & LEVELS & & & \\
\hline $\begin{array}{l}\text { External } \\
\text { Structure of } \\
\text { the Textbooks }\end{array}$ & 1 Point & 2 Points & 3 Points & Score \\
\hline Cover design & $\begin{array}{l}\text { The cover design is } \\
\text { not good }\end{array}$ & $\begin{array}{l}\text { The cover design is } \\
\text { not bad }\end{array}$ & $\begin{array}{l}\text { The cover design } \\
\text { is very good }\end{array}$ & \\
\hline Page layout & $\begin{array}{l}\text { Page layout is not } \\
\text { good }\end{array}$ & $\begin{array}{l}\text { Page design is not } \\
\text { bad }\end{array}$ & $\begin{array}{l}\text { The page design } \\
\text { is very good }\end{array}$ & \\
\hline Colour selection & $\begin{array}{l}\text { Colour selection is } \\
\text { not good, so much } \\
\text { mixed }\end{array}$ & $\begin{array}{l}\text { Colour selection is } \\
\text { not bad }\end{array}$ & $\begin{array}{l}\text { Colour selection } \\
\text { is very good and } \\
\text { harmonious }\end{array}$ & \\
\hline Font style & $\begin{array}{l}\text { The font style is very } \\
\text { bad, it is not legible }\end{array}$ & Font style is not bad & $\begin{array}{l}\text { The font style is } \\
\text { very good and } \\
\text { legible }\end{array}$ & \\
\hline $\begin{array}{l}\text { Compliance of } \\
\text { visual elements } \\
\text { with the content }\end{array}$ & $\begin{array}{l}\text { The visual elements } \\
\text { are not compliant } \\
\text { with the content }\end{array}$ & $\begin{array}{l}\text { The compliance of } \\
\text { visual elements with } \\
\text { the content is not bad }\end{array}$ & $\begin{array}{l}\text { The visual } \\
\text { elements are } \\
\text { compliant with } \\
\text { the content, they } \\
\text { are well } \\
\text { designed }\end{array}$ & \\
\hline Print quality & $\begin{array}{l}\text { Print quality is not } \\
\text { good }\end{array}$ & $\begin{array}{l}\text { Print quality is not } \\
\text { bad }\end{array}$ & $\begin{array}{l}\text { Print quality is } \\
\text { very good }\end{array}$ & \\
\hline
\end{tabular}




\begin{tabular}{|c|c|c|c|c|}
\hline Binding quality & $\begin{array}{l}\text { Binding quality is } \\
\text { not good }\end{array}$ & $\begin{array}{l}\text { Binding quality is not } \\
\text { bad }\end{array}$ & $\begin{array}{l}\text { Binding quality } \\
\text { is very good }\end{array}$ & \\
\hline Paper quality & $\begin{array}{l}\text { Paper quality is not } \\
\text { good }\end{array}$ & $\begin{array}{l}\text { Paper quality is not } \\
\text { bad }\end{array}$ & $\begin{array}{l}\text { Paper quality is } \\
\text { very good }\end{array}$ & \\
\hline Cover quality & $\begin{array}{l}\text { Cover quality is not } \\
\text { good }\end{array}$ & $\begin{array}{l}\text { Cover quality is not } \\
\text { bad }\end{array}$ & $\begin{array}{l}\text { Cover quality is } \\
\text { very good }\end{array}$ & \\
\hline $\begin{array}{l}\text { Size of the } \\
\text { textbook }\end{array}$ & It is hard to use & It is not hard to use & $\begin{array}{l}\text { It is very easy to } \\
\text { use. }\end{array}$ & \\
\hline $\begin{array}{l}\text { Weight of the } \\
\text { textbook }\end{array}$ & Difficult to carry & Not difficult to carry & Easy to carry & \\
\hline Cover carton & Not durable & Durable & $\begin{array}{l}\text { Durable and } \\
\text { very good }\end{array}$ & \\
\hline $\begin{array}{l}\text { The texture of } \\
\text { the paper }\end{array}$ & Rough & Little rough & $\begin{array}{l}\text { Smooth and very } \\
\text { beautiful }\end{array}$ & \\
\hline $\begin{array}{l}\text { Printing } \\
\text { technique }\end{array}$ & The printing is bad & $\begin{array}{l}\text { The printing is not } \\
\text { bad }\end{array}$ & $\begin{array}{l}\text { The printing is } \\
\text { very good }\end{array}$ & \\
\hline \multicolumn{4}{|l|}{ Total Score: } & \\
\hline \multicolumn{4}{|c|}{ Maximum Points to be Obtained: } & 42 \\
\hline
\end{tabular}

The table above is a rubrics example prepared for students to evaluate the textbooks they use. However, this Rubric can only be applied to students if they have the Turkish language proficiency of at least the $B-1$ level.

\section{Analysis and Evaluation Methods:}

After determining the textbooks (including the related workbook and teacher edition of the textbook) used in teaching Turkish as a foreign language to be examined and the case of the problem, it is necessary to determine the research method and the road map to be followed in the study. It can be said that the best research method for examination and evaluation of the textbooks is the mixed methods research design. In its simplest definition, "mixed method (mixed methods research design) is a type of research in which the researcher combines qualitative and quantitative components of the research for the breadth and depth of understanding and corroboration" (Creswell et al., 2015: 4/5), and it can be considered as a suitable research method for examining the textbooks. Because we have the opportunity to obtain data from different sources for examining the textbooks. If the data collection tools are diversified, the reason for the problem is clearly determined and the solution methods of it become better and more accurate. Because "each fact or phenomenon (or truth) has both qualitative and quantitative dimensions" (Yıldırım \& Şimşek, 1993: 351). "A single data source may be insufficient. A single type of evidence may not tell the whole story, or the researcher may not trust the adequacy of a single type of evidence when dealing with the problem"(Creswell et al., 2015: 10). Therefore, the mixed research method has become a frequently preferred research model/design in social sciences in recent years. The data used in the examination of textbooks have quantitative and qualitative nature. Therefore, it is appropriate to conduct research using the mixed method.

Quantitative Data Analyses: Data from quantitative data sources such as the above-mentioned Likert-type scale (or rubrics), semantic scale, and checklists can be imported into the Windows SPSS software package for evaluation and can be analysed using their percentages (\%) and frequencies (F).

Factor analysis is performed to determine the factor structure and sub-dimensions of the scale developed as a result of the application. According to the results of the factor analysis, the items with a factor load below 30 are discarded from the scale. The validity and reliability are important in scored scales. In this regard, the internal consistency coefficient is calculated to determine the reliability of the scale; also, the correlation coefficient between the first and second applications is examined using the test-retest reliability method. 
Also, a "t-test" is performed to determine whether the scores of the participants change by their gender, i.e. whether the scores differ significantly or not.

Then, "One-way ANOVA" or "Kruskal-Wallis H Test" for non-parametric measurements was performed to determine whether the data related to "age, educational status, number of different books used in teaching Turkish as a foreign language, and the experiences" of the participating instructors differ among themselves. Also, for the parametric measurements that differ significantly between each other, "Multiple Comparisons t-test (Fisher's Least Significant Difference-LSD)" can be performed to determine which dimensions show a significant difference.

In the second stage, to evaluate only the formal (external structure) properties of the textbook examined in the research, a questionnaire can be applied to publishing house owners/employees, printing house professionals, graphic and material design experts operating in this field, as well as, the graphic design specialists working in this field in the universities. In this way, the textbook's formal (external structure) properties can be evaluated. As it is known, the formal properties of a textbook are as important as its content. Therefore "With its cover, weight, paper, and carton quality, binding, size, practicability and durability, a textbook need to have the required physical qualities" (Ar1, 2014: 39).

The questionnaire, which is structured in two different forms, can be arranged as a 5-point or 10-point Likert type. Only the formal aspect (external structure) of the textbook(s) examined in the research can be evaluated using the questionnaire, which is designed in two separate forms with a total of 9 questions.

Again, by performing the second questionnaire using a "10-item Likert Scale", the publishing house owners/employees and printing house professionals are intended to evaluate the "Print Quality, Binding Quality, Paper Quality, Cover Quality" of the examined textbooks.

A questionnaire example that can be applied to graphic designers, graphic design specialists working as academics in various faculties is given in the table below.

Table 5: Questionnaire Example that can be Applied to Graphic Design Specialists (Ömeroğlu, 2016)

\begin{tabular}{|c|c|c|c|c|c|c|c|c|c|c|}
\hline \multicolumn{11}{|c|}{$\begin{array}{l}\text { Work experience: ...... } \\
\text { The organization where s/he works: ........ } \\
\text { Title of the textbook: ...... } \\
\text { (Minimum score: } 1, \text { Maximum score: } 10 \text { ) }\end{array}$} \\
\hline Cover design & $\begin{array}{l}1 \\
(\quad) \\
\end{array}$ & $\begin{array}{l}2 \\
(\quad)\end{array}$ & $\begin{array}{l}3 \\
() \\
\end{array}$ & $\begin{array}{l}4 \\
(\quad)\end{array}$ & $\begin{array}{l}5 \\
(\quad) \\
\end{array}$ & $\begin{array}{l}6 \\
(\quad)\end{array}$ & $\begin{array}{l}7 \\
(\quad) \\
\end{array}$ & $\begin{array}{l}8 \\
(\quad) \\
\end{array}$ & $\begin{array}{l}9 \\
(\quad) \\
\end{array}$ & $\begin{array}{l}10 \\
(\quad) \\
\end{array}$ \\
\hline Page layout & $\begin{array}{l}1 \\
(\quad)\end{array}$ & $\begin{array}{l}2 \\
(\quad)\end{array}$ & $\begin{array}{l}3 \\
(\quad)\end{array}$ & $\begin{array}{l}4 \\
(\quad)\end{array}$ & $\begin{array}{l}5 \\
(\quad)\end{array}$ & $\begin{array}{l}6 \\
(\quad)\end{array}$ & $\begin{array}{l}7 \\
(\quad)\end{array}$ & $\begin{array}{l}8 \\
(\quad)\end{array}$ & $\begin{array}{l}9 \\
(\quad)\end{array}$ & $\begin{array}{l}10 \\
(\quad)\end{array}$ \\
\hline $\begin{array}{l}\text { Colour } \\
\text { selection }\end{array}$ & $\begin{array}{l}1 \\
(\quad)\end{array}$ & $\begin{array}{l}2 \\
(\quad)\end{array}$ & $\begin{array}{l}3 \\
()\end{array}$ & $\begin{array}{l}4 \\
(\quad)\end{array}$ & $\begin{array}{l}5 \\
(\quad)\end{array}$ & $\begin{array}{l}6 \\
(\quad)\end{array}$ & $\begin{array}{l}7 \\
(\quad)\end{array}$ & $\begin{array}{l}8 \\
(\quad)\end{array}$ & $\begin{array}{l}9 \\
(\quad)\end{array}$ & $\begin{array}{l}10 \\
(\quad)\end{array}$ \\
\hline Font style & $\begin{array}{l}1 \\
(\quad)\end{array}$ & $\begin{array}{l}2 \\
(\quad)\end{array}$ & $\begin{array}{l}3 \\
(\quad)\end{array}$ & $\begin{array}{l}4 \\
(\quad)\end{array}$ & $\begin{array}{l}5 \\
(\quad)\end{array}$ & $\begin{array}{l}6 \\
(\quad)\end{array}$ & $\begin{array}{l}7 \\
(\quad)\end{array}$ & $\begin{array}{l}8 \\
(\quad)\end{array}$ & $\begin{array}{l}9 \\
(\quad)\end{array}$ & $\begin{array}{l}10 \\
(\quad)\end{array}$ \\
\hline
\end{tabular}




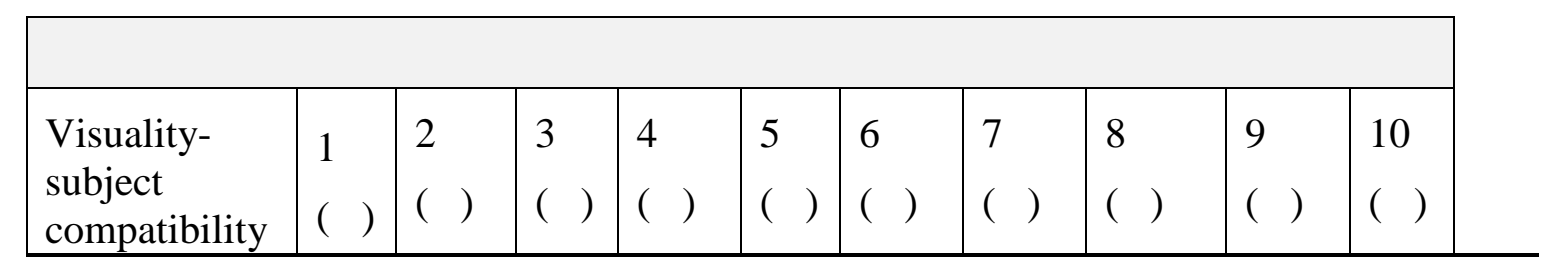

Table 6: Questionnaire Example that can be Applied to Publishing House Owners/Employees and Printing House Professionals (Ömeroğlu, 2016)

\begin{tabular}{|c|c|c|c|c|c|c|c|c|c|c|}
\hline \multicolumn{11}{|c|}{$\begin{array}{l}\text { Details about the interviewee: } \\
\text { Gender: Female ( ) Male ( ) } \\
\text { Age: ....... } \\
\text { Work experience: ...... } \\
\text { The organization where s/he works: ...... } \\
\text { Title of the textbook: ...... } \\
\text { (Minimum score: } 1, \text { Maximum score: } 10 \text { ) }\end{array}$} \\
\hline Print quality & $\begin{array}{l}1 \\
(\quad)\end{array}$ & $\begin{array}{l}2 \\
(\quad) \\
\end{array}$ & $\begin{array}{l}3 \\
(\quad)\end{array}$ & $\begin{array}{l}4 \\
(\quad)\end{array}$ & $\begin{array}{l}5 \\
(\quad) \\
\end{array}$ & $\begin{array}{l}6 \\
(\quad) \\
\end{array}$ & $\begin{array}{l}7 \\
(\quad) \\
\end{array}$ & $\begin{array}{l}8 \\
()\end{array}$ & $\begin{array}{l}9 \\
(\quad) \\
\end{array}$ & $\begin{array}{l}10 \\
(\quad)\end{array}$ \\
\hline $\begin{array}{l}\text { Binding } \\
\text { quality }\end{array}$ & $\begin{array}{l}1 \\
(\quad)\end{array}$ & $\begin{array}{l}2 \\
(\quad) \\
\end{array}$ & $\begin{array}{l}3 \\
(\quad)\end{array}$ & $\begin{array}{l}4 \\
(\quad)\end{array}$ & $\begin{array}{l}5 \\
(\quad) \\
\end{array}$ & $\begin{array}{l}6 \\
(\quad) \\
\end{array}$ & $\begin{array}{l}7 \\
(\quad) \\
\end{array}$ & $\begin{array}{l}8 \\
()\end{array}$ & $\begin{array}{l}9 \\
(\quad)\end{array}$ & $\begin{array}{l}10 \\
(\quad)\end{array}$ \\
\hline Paper quality & $\begin{array}{l}1 \\
(\quad)\end{array}$ & $\begin{array}{l}2 \\
()\end{array}$ & $\begin{array}{l}3 \\
(\quad)\end{array}$ & $\begin{array}{l}4 \\
(\quad)\end{array}$ & $\begin{array}{l}5 \\
(\quad)\end{array}$ & $\begin{array}{l}6 \\
()\end{array}$ & $\begin{array}{l}7 \\
()\end{array}$ & $\begin{array}{l}8 \\
(\quad)\end{array}$ & $\begin{array}{l}9 \\
(\quad)\end{array}$ & $\begin{array}{l}10 \\
(\quad)\end{array}$ \\
\hline Cover quality & $\begin{array}{l}1 \\
(\quad)\end{array}$ & $\begin{array}{l}2 \\
(\quad) \\
\end{array}$ & $\begin{array}{l}3 \\
(\quad)\end{array}$ & $\begin{array}{l}4 \\
(\quad)\end{array}$ & $\begin{array}{l}5 \\
(\quad) \\
\end{array}$ & $\begin{array}{l}6 \\
(\quad) \\
\end{array}$ & $\begin{array}{l}7 \\
(\quad) \\
\end{array}$ & $\begin{array}{l}8 \\
(\quad) \\
\end{array}$ & $\begin{array}{l}9 \\
(\quad) \\
\end{array}$ & $\begin{array}{l}10 \\
(\quad) \\
\end{array}$ \\
\hline
\end{tabular}

Qualitative Data Analyses:

It is required to consider some rules while analysing qualitative data. To ensure objectivity in qualitative data digitization of data can be performed. Although the numbers and figures are often associated with quantitative research methods, the qualitative data can be rendered as numbers at a certain level. The data obtained through interviews, observations, or document review techniques in the qualitative study can be quantified by performing certain processes and converting them into numbers or figures. The main goal of this operation is that digitization increases reliability. Thus stability, repeatability, and accuracy are ensured (Weber, 1985: 24). Thus, objectivity can be achieved by eliminating bias and relativity in the analysis of qualitative data. However, as Patton (2014) points out, "the objectivity should never be understood as 'objectifying' the qualitative data. Because absolute 'objectivity' is an effort that cannot be achieved." However, "quantification of qualitative data is a form of [a kind of] data analysis and can result in a more 'fair' way of making interpretations. Qualitative data can be quantified by using simple percentage and word frequency calculations" (Y1ldırım et al., 1999: 275). However, all these data collection tools described above have positive and negative aspects. Kılıç (et al., 2011: 199) show these positive and negative aspects in the table below. 
Table 7: Positive and Negative Aspects of Data Collection Tools

\begin{tabular}{|c|c|c|}
\hline Tools & Positive aspects & Limitations \\
\hline Likert-type Scale & $\begin{array}{l}\text { It is easy to score. } \\
\text { All affective properties } \\
\text { related to the textbook can } \\
\text { be measured. It is effective } \\
\text { in revealing some attitudes } \\
\text { that are difficult to observe. }\end{array}$ & $\begin{array}{l}\text { Levels being close to each } \\
\text { other } \\
\text { makes it difficult for } \\
\text { respondents to make } \\
\text { decisions. }\end{array}$ \\
\hline Rubrics & $\begin{array}{l}\text { It provides an opportunity } \\
\text { for valid and reliable } \\
\text { measurement. } \\
\text { Since the levels are } \\
\text { definitely separated, it is } \\
\text { easier for respondents to } \\
\text { make decisions. } \\
\text { It is easy to use. } \\
\text { It can be applied in different } \\
\text { areas. } \\
\text { It gives consistent results } \\
\text { even with different scoring. }\end{array}$ & $\begin{array}{l}\text { It takes time to prepare. } \\
\text { It is difficult to identify the } \\
\text { levels. }\end{array}$ \\
\hline Checklist & $\begin{array}{l}\text { It is easy to prepare. } \\
\text { Several options can be } \\
\text { selected in some checklists. }\end{array}$ & $\begin{array}{l}\text { Its reliability and validity are } \\
\text { low. It is difficult to analyse. }\end{array}$ \\
\hline Semantic Scales: & $\begin{array}{l}\text { Different types of data can } \\
\text { be collected together. } \\
\text { It allows us to ask different } \\
\text { types of questions. } \\
\text { It is easy to score. }\end{array}$ & $\begin{array}{l}\text { It may be difficult for the } \\
\text { responder to decide on } \\
\text { answer options. } \\
\text { It is difficult to grade more } \\
\text { than three answer options. }\end{array}$ \\
\hline
\end{tabular}

The qualitative and quantitative data obtained from different sources mentioned above should be analysed following a holistic approach. Otherwise, an accurate result may not be obtained from the research.

\section{Conclusion and Recommendations}

In this study, it is explained how to choose and investigate the textbooks used/to be used in teaching Turkish as a foreign language; also, the questions such as how to examine textbooks used in this field, which research method to be applied, and from which sources the data can be obtained are answered. Therefore, it is estimated that this article will fill the gap in the literature and guide the researchers. As it is known, "textbooks are the main source of reference for teachers and students despite other modern course tools developed" (Kolaç, 2003: 137). Therefore, the textbooks used in foreign language teaching should be qualified and functional according to scientific criteria. Republic of Turkey Ministry of National Education (MEB) establishes the criteria for textbooks to be taught in primary and secondary education in Turkey. While the textbooks to be taught in primary and secondary education are determined by MEB, there are no formal criteria for the textbooks to be used in teaching Turkish as a foreign language. However, "Common European Framework of Reference for Language- (CEFRL)" (Web1) prepared by the Council of Europe and the decisions taken by the Council at the meeting in Stockholm (Stockholm Criteria) can be considered as the criteria to be followed in this regard. As known, Turkey is the oldest member of the Council of Europe (1949) and usually follows the decisions of the Council. The Council of Europe declared 2001 as the European Year of Languages and took a series of decisions. At the meeting held in Strasbourg, the 
Common European Framework of Reference for Languages (CEFRL) accepted the project of developing EURO PASS and established the language proficiency levels as $A-1, A-2 ; B-1, B-2 ; C-1$, and $C$-2. Besides, with the concept of Intercultural Competence, it has developed and implemented projects to increase mutual communication between European citizens of different cultures living in Europe and to ensure the preservation of multilingualism and multiculturalism (Web2). Therefore, it is required to comply with the Council's criteria on the textbooks used in teaching Turkish as a foreign language and teaching foreign languages in the member countries of the Council.

The data for the study on textbooks used in foreign language teaching can be obtained both qualitatively and quantitatively as in the Ömeroğlu's (2016) $\mathrm{PhD}$ thesis on the most common four textbooks that are used in Turkey and in the Turkish Language Teaching Centres in various regions of the world. The qualitative data can be obtained from interviews with those using the textbooks (teachers and students), field/observation notes, semantic scales and checklists to be applied for the textbook(s) subject to the investigation. Also, these data can be obtained from a questionnaire to be applied to specialists dealing with book design and publishing works (design professionals, printing house professionals, publishing house employees, and academics interested in this field). On the other hand, the quantitative data can be obtained from the 5-point Likert-type scale that can be applied to instructors using the book. All this data is analysed using a mixed research method to obtain results and conclude the research. As Creswell (et al., 2015: 15) says the mixed research method "helps to answer questions that cannot be answered by qualitative or quantitative research method alone". In this respect, the mixed research method can be accepted as an appropriate research design/model in studies on textbooks.

It is thought that all the above-mentioned information, developed scales, application examples, and criteria will help instructors and researchers in choosing a textbook to be used for teaching a foreign language or in research studies on textbooks.

\section{References}

[1.] Andrade, H.G. (1997). Understanding Rubrics, Educational Leadership, 54(4).

[2.] Arı, G. (2014). Türkçe Ders Kitaplarında Fiziksel ve Biçimsel Görünüm. H. Ülper (Edit.) (Press 3) Türkçe Ders Kitabı Çözümlemeleri. Ankara: Pegem A. Yayınları.

[3.] Bamberger, R. (1975). Promating the Reading Habit. Paris: Published by the UNESCO Press.

[4.] Creswell, J W., V. L. P. Clark (2015). Karma Yöntem Araştırmaları, Tasarımı ve Yürütülmesi. (Çeviri Edit: Dede, Demir vd.) Ankara: Anı Yayıncılık.

[5.] Demirel, Ö. ve E. Altun (2012). Öğretim Teknolojileri ve Materyal Tasarımı. (Press 7) Ankara: Pegem A. Yayınları.

[6.] Güneş, F. (2002). Ders Kitaplarının İncelenmesi. Ankara: Ocak Yayınları.

[7.] Karasar, N. (2013). Bilimsel Araştırma Yöntemi. (Press 25) Ankara: Nobel A. Yayıncılık.

[8.] Kılıç, A., S. Seven (2011). Konu Alanı Ders Kitabı İncelemesi. Ankara: Pegem A. Yayınları.

[9.] Kolaç, E. (2003). İlköğretim Dördüncü Sınıf Türkçe Ders Kitaplarının Öğretmen Görüşlerine Dayalı Olarak Değerlendirilmesi. Uludă̆ Üniversitesi Eğitim Fakültesi Dergisi 17(1): 105-137.

[10.] Küçükahmet, L. (2011). Öğretim Illke ve Yöntemleri. Ankara: Nobel A. Yayınları

[11.] Ömeroğlu, E. (2016). Yabancılara Türkçe Öğretimi İçin Kullanılan Ders Kitaplarının İncelenmesi. Sakarya Üniversitesi Eğitim Bilimleri Enstitüsü, Yayımlanmamış Doktora Tezi.

[12.] Parlak, B., N. Doğan (2014). Dereceli Puanlama Anahtarı ve Puanlama Anahtarından Elde Edilen Puanların Uyum Düzeyleri. Hacettepe Üniversitesi Ĕgitim Fakültesi Dergisi (H. U. Journal of Education) 29(2), 189-197-Nisan.

[13.] Patton, M. Q. (2014). Nitel Araştırma ve Değerlendirme Yöntemleri. (3. Baskıdan Çeviri) Ankara: Pegem A. Yayınları.

[14.] Richaudeau, F., F. Gauquelin (1997). Lecture Rapide Richaudeau. Paris: Editions Retz.

[15.] Tekin, H. (2019). Ĕgitimde Ölçme ve Değerlendirme. (Press 27). Ankara: Yarg1 Yayınevi.

[16.] Tomlinson, B., I. McGrath (2002). Materials Evaluation and Design for Language Teaching. Edinburg: Edinburg University Press.

[17.] Web1. Link: http://europass.cedefop.europa.eu/tr/documents/european-skills_passport/languagepassport/templates-instructions 
[18.] Web2. Link: https://www.coe.int/en/web/portfolio/the-common-european-framework-of-referencefor-languages-learning-teaching-assessment-cefr-

[19.] Weber, R. P. (1985). Basic Content Analysis. Harvard University Press.

[20.] Yıldırım, A., H. Şimşek (2013). Sosyal Bilimlerde Nitel Araştırma Yöntemleri. (Press 9) Ankara: Seçkin Yayıncılık. 